\title{
Body temperatures of an arboreal monitor lizard, Varanus tristis (Squamata: Varanidae), during the breeding season
}

\author{
G.G. Thompson ${ }^{1}$, E.R. Pianka ${ }^{2}$, M. de Boer ${ }^{3}$ \\ ${ }^{1}$ Centre for Ecosystem Management, Edith Cowan University, 100 Joondalup Drive, Joondalup, Western \\ Australia, 6027, Australia \\ e-mail: G.Thompson@cowan.edu.au \\ ${ }^{2}$ Department of Zoology, University of Texas at Austin, Austin, Texas 78712-1064, USA \\ ${ }^{3}$ Hogeschool Holland, Postbus 261, 1110 AG Diemen, The Netherlands
}

Based on a sample of cloacal body temperatures taken from four species of varanids in the semi-arid regions of Western Australia, Pianka (1994) reported Varanus eremius and $V$. gouldii to be good thermoregulators, while arboreal V. caudolineatus and V. tristis did not regulate as well. In addition, the mean body temperature for $V$. tristis $\left(34.8^{\circ} \mathrm{C}\right)$ was significantly lower than that for $V$. eremius $\left(37.3^{\circ} \mathrm{C}\right), \mathrm{V}$. gouldii $\left(37.7^{\circ} \mathrm{C}\right)$ and $V$. caudolineatus $\left(37.8^{\circ} \mathrm{C}\right)$. Pianka's (1994) temperature recordings were taken on live varanids collected opportunistically in the field.

Our objective was to determine if the body temperature of $V$. tristis in the western Great Victoria Desert during the part of the day (1100 to $1800 \mathrm{~h}$ ) when the lizards are active are generally lower than body temperatures reported for other varanids.

Methods. The study site in the Great Victoria Desert $\left(28^{\circ} 12^{\prime} \mathrm{S}, 123^{\circ} 35^{\prime} \mathrm{E}\right)$ is a complex mosaic of sandridges and interdunal flats with a vegetation of spinifex (Triodia basedowii), Marble Gum trees (Eucalyptus gongylocarpa), Mallee trees (Eucalyptus concinna), Acacia (Acacia aneura and others) and other small bushes and grasses.

Seven $V$. tristis tristis were captured after following their tracks to a retreat in a hollow $\log$ or hollow tree branch between 11 and 29 September, 1995. After determining sex (everting hemipenes), weighing and measuring [snout-to-vent length (SVL) and total length (TL)] a miniature radio-transmitter $(7 \mathrm{~g}$, approximately $21 \mathrm{~mm} \times 12 \mathrm{~mm} \times 5 \mathrm{~mm}$; less than 5\% of body mass) from Holohil Systems, Canada was surgically inserted into its abdominal cavity. Transmitters were removed at the conclusion of the experiment using a similar procedure. Lizards were held overnight and released at their place of capture the next day. Surgical procedures and transmitters seemed to have little impact on lizard behaviour, as movement or activity patterns of $V$. tristis during the first seven days after 
release did not differ from those over the subsequent seven days. One V. tristis subsequently laid ten eggs while she contained an internal transmitter, nine of which hatched.

Temperature sensitive transmitters issued a sound pulse, the period between pulses decreasing with increased body temperature. The interval between beeps was recorded to the nearest 0.01 second (using a stopwatch) numerous times throughout the day from 11 September until 8 November, 1995. Collection of data for most lizards was terminated before 8 November when battery power for transmitters became insufficient to detect the signal from a distance. This did not affect the pulse rate for temperature sensitive transmitters but only the strength of the signal. A Biotelemetry receiver (RX3) with a 3EY directional antenna operating in the $150-151.5 \mathrm{MHz}$ band was used to determine body temperatures at multiple times during the day.

Before implantation, temperature sensitive transmitters were calibrated in a water bath at seven temperatures between 10 and $40^{\circ} \mathrm{C}$. The curvilinear relationship between temperature and time between pulses was determined by fitting a quadratic equation to the data. Visual inspection of the fitted line indicated no value deviated by more than $1{ }^{\circ} \mathrm{C}$ from the line.

Results. One Varanus tristis could not be located using its transmitter after 5 days, so data for this lizard were excluded from all analyses. Four hundred and fifty-three separate body temperature $\left(T_{b}\right)$ observations were taken for the remaining six V. tristis (table 1). Mean field maximum $T_{b}$ for six $V$. tristis was $40.0^{\circ} \mathrm{C}( \pm s 1.75, n=6)$. To establish the overall pattern of thermoregulation, mean $T_{b}$ for six $V$. tristis were calculated for each $\mathrm{h}$ between 0600 and $2100 \mathrm{~h}$ and are plotted in figure 1 . Mean $T_{b}$ between 1100 and $1800 \mathrm{~h}$, the activity period, was $33.2^{\circ} \mathrm{C}( \pm s 4.27)$. Mean $T_{b}$ ranged between 32 and $35^{\circ} \mathrm{C}$ when calculated for hourly periods between 1100 and $1800 \mathrm{~h}$ (fig. 1). Large standard deviations shown in figure 1 indicate a wide variation in $T_{b}$ among days, and as the lizards' increase their $T_{b}$ in the morning. The pattern of thermoregulation indicated that $V$. tristis have a relatively rapid increase in $T_{b}$ after $0815 \mathrm{~h}$ which peaks about $1330 \mathrm{~h}$.

Body temperatures of five $V$. tristis were recorded hourly between 0600 and $2000 \mathrm{~h}$ for a 'typical' day (4 October; minimum ambient temperature $\left(T_{a}\right)$ of $12^{\circ} \mathrm{C}$, maximum

Table 1. Sex, mass, snout-to-vent length, number of observations and maximum body temperature for $V$. tristis.

\begin{tabular}{lllllll}
\hline & \multicolumn{3}{l}{ Identification letter } & & & \\
\cline { 2 - 7 } & $\mathrm{B}$ & $\mathrm{D}$ & $\mathrm{E}$ & $\mathrm{F}$ & $\mathrm{G}$ & $\mathrm{H}$ \\
\hline Body mass $(\mathrm{g})$ & 265 & 220 & 280 & 218 & 300 & 343 \\
SVL $(\mathrm{mm})$ & 272 & 252 & 276 & 250 & 274 & 288 \\
Sex & $\mathrm{m}$ & $\mathrm{f}$ & $\mathrm{m}$ & $\mathrm{f}$ & $\mathrm{m}$ & $\mathrm{f}$ \\
Total number of days monitored & 55 & 28 & 45 & 23 & 47 & 21 \\
Total number of temperature observations & 61 & 69 & 92 & 76 & 86 & 69 \\
Mean $T_{b}$ & 30.1 & 28.1 & 29.3 & 27.9 & 27.9 & 26.5 \\
Maximum $T_{b}$ recorded & 39.0 & 38.1 & 42.5 & 39.9 & 41.6 & 38.7 \\
\hline
\end{tabular}




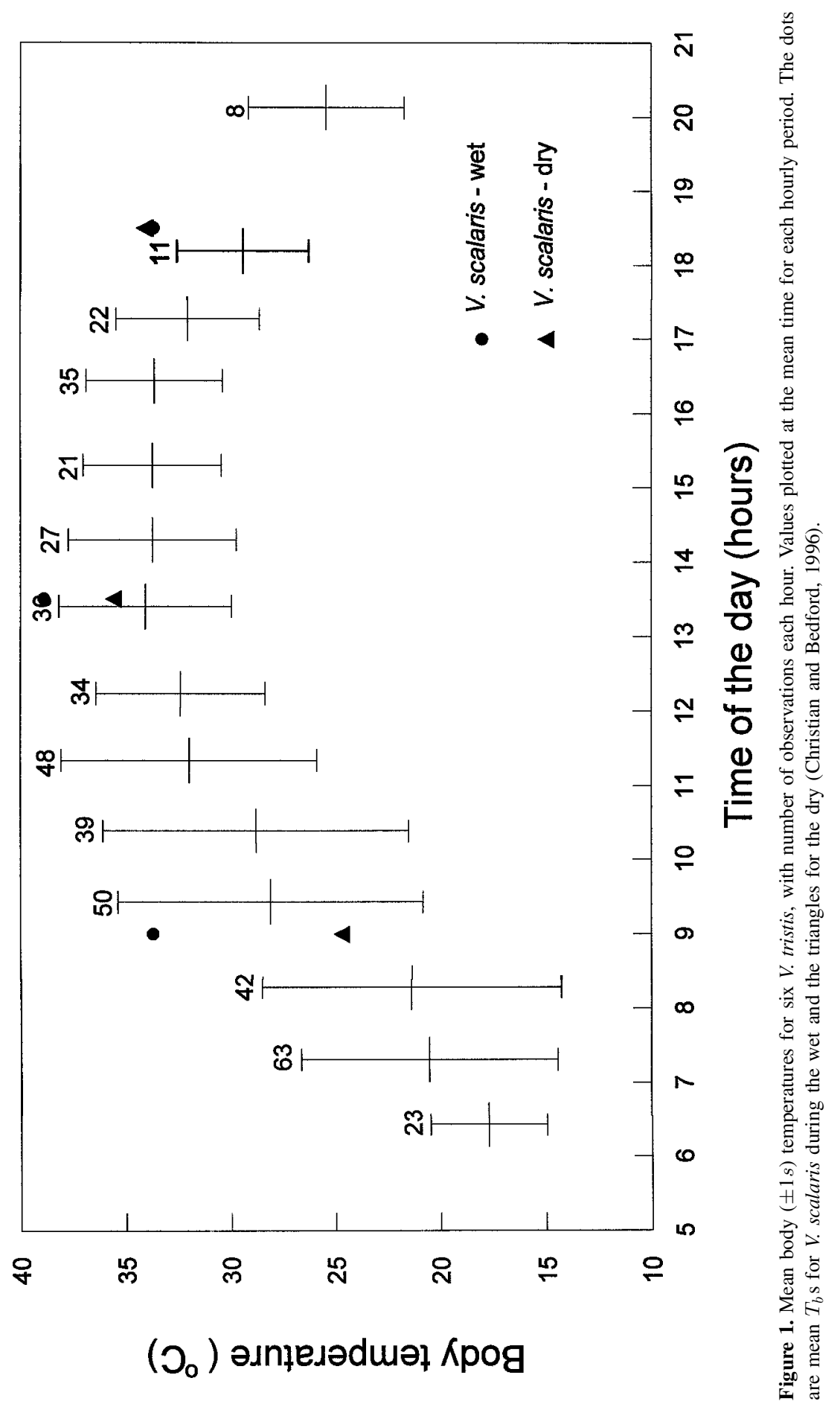


$T_{a}$ of $33^{\circ} \mathrm{C}$, maximum wind speed $2.6 \mathrm{~m} \mathrm{sec}^{-1}$ with minimal cloud cover; $T_{a}$ conditions were recorded at Yamarna weather station approximately $8 \mathrm{~km}$ north east of the study site) in the middle of the study period. This example provides an indication of the extent of individual variation and individual concurrence with the overall pattern. There was no significant difference in the $T_{b}$ s of the five V. tristis measured hourly (repeated measures ANOVA $F_{4,52}=1.24, P=0.304$ ) on 4 October. The greatest variation occurred during the late morning increase in $T_{b}$ to a relatively constant $T_{b}$ between 30 and $34^{\circ} \mathrm{C}$ (between 1215 and $1430 \mathrm{~h}$ ) and again between 1430 and $1700 \mathrm{~h}$ after which $T_{b}$ s again converged until about $1815 \mathrm{~h}$. This variation in the morning probably reflects the time that each V. tristis emerged to bask.

Discussion. The highest $T_{b}$ for six $V$. tristis ranged between 38.7 and $42.5^{\circ} \mathrm{C}$ with a mean of $40^{\circ} \mathrm{C}$. Pianka (1994) reports unusually high maximum body temperatures of $44.2^{\circ} \mathrm{C}$ and $47.3^{\circ} \mathrm{C}$ for two $V$. tristis. Both of these temperatures are appreciably higher than the maximum recorded in this study. The critical thermal maximum for $V$. tristis is unknown. However, a body temperature of $47^{\circ} \mathrm{C}$ is close to the lethal limit for most lizards (Curry-Lindahl, 1979) and above that for $V$. griseus $\left(43^{\circ} \mathrm{C}\right.$, Vernet et al., $1988)$, V. olivaceus (41.6- $42.4^{\circ} \mathrm{C}$, Auffenberg, 1988), V. komodoensis $\left(42.7^{\circ} \mathrm{C}\right.$, Auffenberg, 1981) and $V$. bengalensis $\left(42.3-44.7^{\circ} \mathrm{C}\right.$, Auffenberg, 1994). These high values might have resulted from forcing these two $V$. tristis into locations that increased their body temperature while they were being located or caught. A fleeing V. tristis will probably take temporary refuge anywhere to avoid being caught and may have moved to a position that increased its body temperature to levels that it would normally avoid.

Mean $T_{b}$ between 1100 and $1800 \mathrm{~h}$ was $33.2^{\circ} \mathrm{C}$. Christian and Bedford (1996) report pre-dawn $T_{b}$ for the slightly-smaller, arboreal $\mathrm{V}$. scalaris (from the tropics of northern Australia) in the wet season as $21.7^{\circ} \mathrm{C}$ and $18.5^{\circ} \mathrm{C}$ in the dry season; during the morning (0700-1100 h) the mean $T_{b}$ was $33.7^{\circ} \mathrm{C}$ in the wet and $24.7^{\circ} \mathrm{C}$ in the dry; around midday (1100-1600 $\mathrm{h}$ ) the mean $T_{b}$ as $38.9^{\circ} \mathrm{C}$ in the wet and $35.6^{\circ} \mathrm{C}$ in the dry; and in the late afternoon (1600-2100 h) the mean $T_{b}$ as $33.7^{\circ} \mathrm{C}$ in the wet and $34.1^{\circ} \mathrm{C}$ in the dry. These mean $T_{b} \mathrm{~s}$ for $V$. scalaris are generally significantly higher than the comparable mean temperatures for the same time periods for $V$. tristis [in the morning $(0700-1100 \mathrm{~h}, 24.3$ $\pm 7.80^{\circ} \mathrm{C}, t_{193}=16.47$ for $V$. scalaris the wet season, $P<0.05$ ), and around mid-day $\left(1100-1600 \mathrm{~h}, 33.0 \pm 4.71{ }^{\circ} \mathrm{C}, t_{159}=15.88\right.$ for $V$. scalaris the wet, $t_{159}=7.01$ for the dry, $P<0.05$, respectively), and in late afternoon $\left(1600-2100 \mathrm{~h}, 31.6 \pm 4.17^{\circ} \mathrm{C}, t_{75}\right.$ $=4.15$ for $V$. scalaris the wet, $t_{75}=4.99$ for the dry, $P<0.05$, respectively)] in the Great Victoria Desert during September to October (fig. 1). This would suggest the $T_{b}$ of $V$. tristis when it was able to thermoregulate was generally lower than that for $V$. scalaris during their active periods.

Comparative body temperatures for other varanids are generally higher than those reported here for V. tristis (table 2) thus supporting Pianka's (1994) general statement that the active body temperature for $V$. tristis is lower than that for other varanids. Field active 


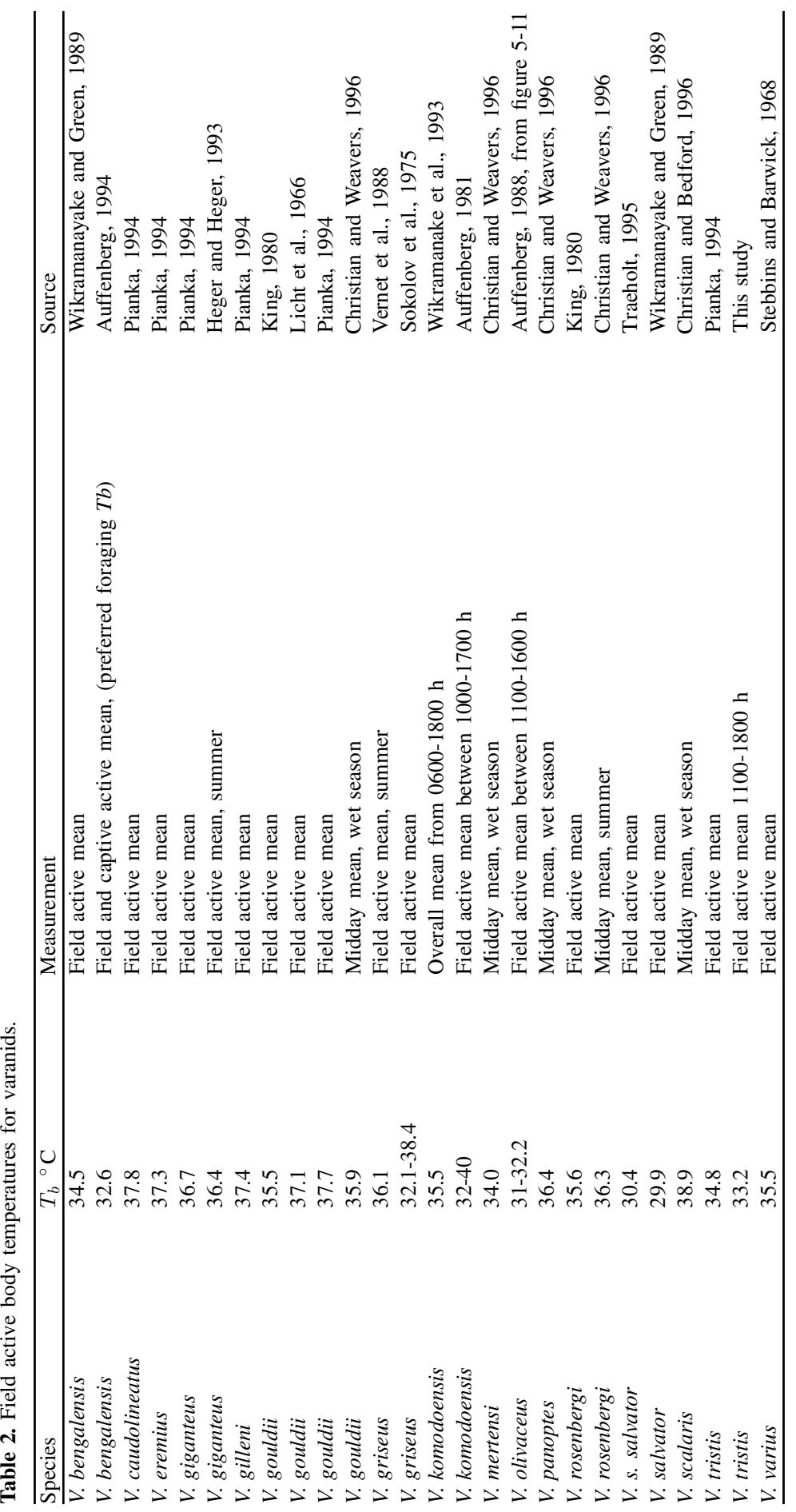


$T_{b}$ for the semi-aquatic $V$. mertensi and $V$. salvator are generally lower than for terrestrial species, as are the field active $T_{b}$ of $V$. olivaceus and $V$. bengalensis. These lower body temperatures probably are associated with their choice of habitat (Wikramanayake and Green, 1989). Whether the generally lower $T_{b}$ for $V$. tristis compared with other terrestrial varanids reflects a physiological difference or a variation based on the season or how it uses its habitat is unknown. Christian and Weavers (1996) report significant differences within and between seasons in $T_{b}$ among varanid species (V. panoptes, V. gouldii and V. mertensi) living in tropical northern Australia. Varanus tristis is a dark-bodied, widelyforaging, arboreal varanid from the subgenus Odatria that is found in a variety of habitats in the northern four-fifths of Australia. In the Great Victoria Desert, V. tristis have large activity areas, move almost in a direct line from tree to tree and seldom deviate to forage during the breeding season, are possibly ambush predators that change their perches regularly (Thompson et al., 1999). Before a conclusive statement can be made on their relative $T_{b}$, the field active $T_{b}$ for $V$. tristis from other parts of the Australian continent should be examined.

Varanus tristis generally began increasing their $T_{b}$ from when it was first recorded in the morning (from about $0600 \mathrm{~h}$ ) probably as a result of conductive heat gain. A more rapid increase was generally evident after $0930 \mathrm{~h}$, which was probably due to heat gain by radiation occurring when $V$. tristis bask on a tree limb. Small peaks in $T_{b}$ at about $1100 \mathrm{~h}$ evident in 3 of 5 individuals monitored hourly on October 4 could correspond to the end of the initial basking activity often evident in varanids (King, 1980; King et al., 1989; Green et al., 1991). Comparative data for five individual $V$. tristis on 4 October, when ambient temperature at $0600 \mathrm{~h}$ was $19^{\circ} \mathrm{C}$, at $0900 \mathrm{~h}$ was $25.5^{\circ} \mathrm{C}$ and the maximum was $33^{\circ} \mathrm{C}$, suggest consistency among individuals in how $V$. tristis regulate their $T_{b}$ during the breeding season.

Acknowledgements. T. Pusey, N. Kirkwood and G.A. Pianka are thanked for providing assistance with the surgery, and G.A. Pianka assisted with field work. S. Sweet gave useful advice on surgically implanting transmitters. The Western Australian Department of Conservation and Land Management licensed collection of animals. Experiments were undertaken with the approval of the Animal Ethics Committee of Edith Cowan University. Edith Cowan University provided some funds for this research. ERP thanks the graduate school of University of Texas at Austin for a faculty research assignment and the Denton A. Cooley Centennial Professorship of Zoology for funding part of this project.

\section{References}

Auffenberg, W. (1981): The Behavioral Ecology of the Komodo Monitor. Gainesville, University Press of Florida.

Auffenberg, W. (1988): Gray’s Monitor Lizard. Gainesville, University Press of Florida.

Auffenberg, W. (1994): The Bengal Monitor, Gainesville, University Press of Florida.

Christian, K., Bedford, G. (1996): Thermoregulation by the spotted tree monitor Varanus scalaris, in the seasonal tropics of Australia. J. Therm. Biol. 21 (2): 67-73.

Christian, K.A., Weavers, B.W. (1996): Thermoregulation of monitor lizards in Australia: an evaluation of methods in thermal biology. Ecol. Monogr. 66: 139-157. 
Curry-Lindahl, K. (1979): Thermal ecology of the tree agama (Agama atricollis) in Zaire with a review of heat tolerance in reptiles. J. Zool. Lond. 188: 185-220.

Green, B., King, D., Braysher, M., Saim, A. (1991): Thermoregulation, water turnover and energetics of free-living Komodo dragons, Varanus komodoensis . Comp. Biochem. Physiol. 99A: 97-101.

Heger, N.A., Heger, T.G. (1993): Thermoregulation, activity pattern, and home range variation in the large monitor lizard, Varanus giganteus. Abstracts of the Second World Congress of Herpetology, Adelaide, 29 December, 1993 to January 6, 1994: 115-116.

King, D. (1980): The thermal biology of free-living sand goannas (Varanus gouldii) in southern Australia. Copeia 1980: 755-767.

King, D., Green, B., Butler, H. (1989): The activity pattern, temperature regulation and diet of Varanus giganteus on Barrow Island, Western Australia. Aust. Wildl. Res. 16: 41-47.

Licht, P., Dawson, W.R., Shoemaker, V.H. (1966): Observations on the thermal relations of Western Australian lizards. Copeia 1966: 97-110.

Pianka, E.R. (1994): Comparative ecology of Varanus in the Great Victoria Desert. Aust. J. Ecol. 19: 395-408.

Sokolov, V.E., Sukhov, V.P., Chernyshov, Y.M. (1975): A radiotelemetric study of diurnal fluctuations of body temperature in the desert monitor (Varanus griseus). Zoological Zhurnal 54: 1347-1356.

Stebbins, R.C., Barwick, R.E. (1968): Radiotelemetric study of thermoregulation in a lace monitor. Copeia 1968: $541-547$.

Traeholt, C. (1995): A radio-telemetric study of the thermoregulation of free-living water monitor lizards, Varanus s. salvator. J. Comp. Physiol. B 165: 125-131.

Thompson, G.G., de Boer, M., Pianka, E.R. (1999): Activity areas and daily movements of an arboreal monitor lizard, Varanus tristis (Squamata: Varanidae) during the breeding season. Aust. J. Ecol., In press.

Vernet, R., Lemire, M., Grenot, C., Francaz, J.-M. (1988): Ecophysiological comparisons between two large Saharan lizards, Uromastic acanthinurus (Agamidae) and Varanus griseus (Varanidae). J. Arid. Environ. 14: $187-200$.

Wikramanayake, E.D., Green, B. (1989): Thermoregulatory influences on the ecology of two sympatric varanids in Sri Lanka. Biotropica 21: 74-79.

Wikramanayake, E.D., Marcellini, D., Ridwan, W. (1993): The thermal ecology of adult and juvenile komodo dragons, Varanus komodoensis. Abstracts of the Second World Congress of Herpetology, Adelaide, 29 December, 1993 to January 6, 1994: 284.

Received: March 20, 1998. Accepted: May 29, 1998. 